\title{
1 \\ U.S. GEOLOGICAL SURVEY GROUND-WATER STUDIES IN IOWA
}

\section{GROUND-WATER ISSUES}

Ground water is the primary source for most water uses in lowa. Ground-water resources supply 81 percent of the water withdrawn in lowa for non-power-generating uses. Ground water from five principal aquifer systems is the source of drinking water for approximately 82 percent of the State's population. These aquifers range from land surface to several thousand feet below land surface. Land use in lowa is predominately agricultural; about 93 percent of the land is farmed. The major issues related to ground water in lowa are:

- Nonpoint pollution from agricultural chemicals,

- Contamination by hazardous wastes, and

- Limitations on use owing to quantity or the natural quality

\section{U.S. GEOLOGICAL SURVEY PROGRAMS}

The U.S. Geological Survey (USGS) is the principal source of scientific and technical expertise in the earth sciences within the Federal government. USGS activities include research and services in the fields of geology, hydrology, and cartography. The mission of the Water Resources Division of the USGS is to develop and disseminate information on the Nation's water resources. In lowa, the activities of the Water Resources Division are conducted by scientists, technicians, and support staff in offices in Iowa City, Fort Dodge, and Council Bluffs.

Hydrologic-data stations are maintained at selected locations throughout lowa to record data on stream stage and discharge, ground-water levels, quality of precipitation, and the quality of surface and ground water. Water-resources data are stored in the USGS National Water Data Storage and Retrieval System data base. These data are used by water planners and others involved in decisions that affect lowa's water resources.

The USGS, in cooperation with Federal, State, and local agencies, maintained a network of more than 250 observation wells to monitor fluctuations of water levels during 1987 . Waterlevel measurements from wells are used to monitor ground-water trends; however, additional useful information about the groundwater resource may be interpreted from these measurements when they are integrated with other observations and groundwater investigations.

During 1987, the USGS also maintained a network of about 1,200 monitoring wells in lowa to describe the long-term chemical quality of water in the major aquifer systems. Wells are sampled at frequencies of 1 to 7 years, depending on their susceptibility to contamination. About 200 wells are sampled annually. The network originally was designed to emphasize collection of data on pesticides and volatile organic constituents. Chemical data from these wells provide water planners and others with information on the trends in the quality of ground water in lowa as well as information needed to direct waterquality sampling and assessment in areas of regional concern.

The USGS has conducted more than $\mathbf{5 0}$ hydrologic investigations in lowa. During fiscal year 1987, the USGS entered into agreements with 15 Federal, State, and local agencies involving 18 hydrologic investigations in Iowa; nine investigations included studies of ground-water quantity and quality. Two examples of ground-water investigations by the USGS that address specific ground-water issues in lowa are discussed in the following sections.

\section{Ground-Water Resources, Statewide}

Ground water of quality suitable for most uses, in adequate amounts, is unevenly distributed throughout lowa. The need to describe the occurrence, availability, and natural quality of ground water within lowa has resulted in a series of investigations in cooperation with the Geological Survey Bureau (GSB), formerly the Iowa Geological Survey, of the Iowa Department of Natural Resources (DNR). The investigations, begun in the early 1960's, to map and describe the occurrence, extent, yield, and quality of water in the principal aquifers of nine regions within lowa is resulting in a series of Water Atlases published

\section{STUDY AREAS}

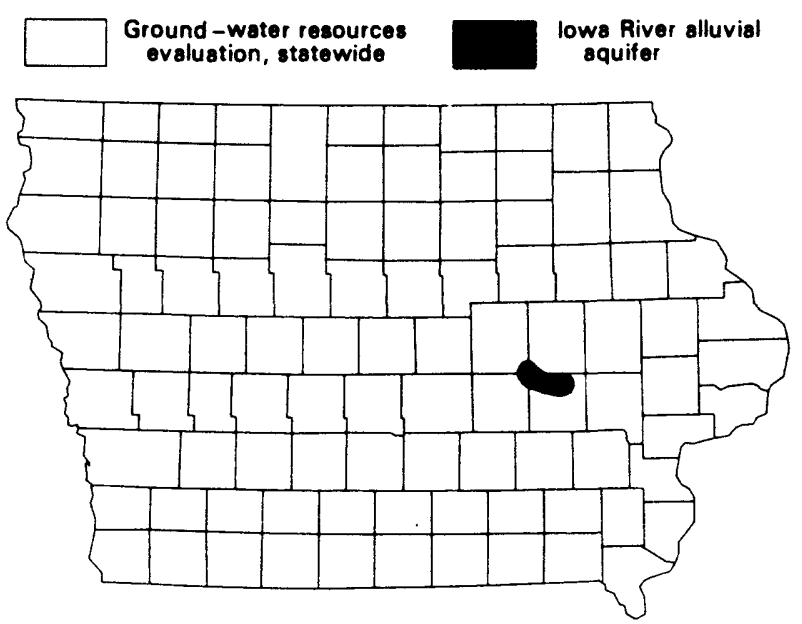


by the GSB. Data from the files of the USGS and the DNR, as well as local water managers and well drillers, are used in conjuction with information collected in the field to compile the repons. The Water Atlases are important ground-water-resource references to the general public as well as to State and local water managers. Upon completion of current work in southwestern Iowa, mapping and preliminary evaluation of the ground-water resources of the entire State will be completed. Information from these studies is used by State agencies to manage public and private water-resources development. including development of private water supplies and evaluations of water supplies for industrial development. The reports are used by State and local planners, water-well drillers, and the general public for specific information about sources of water at site-specific locations.

\section{Iowa River Alluvial Aquifer}

The occurrence of undesirable concentrations of nitrate and other agricultural chemicals in shallow ground water has caused increasing concern. Nitrate and pesticides concentrations in some private and municipal water supplies from alluvial aquifers exceed acceptable levels. From 1984 through 1986, the USGS, in cooperation with the GSB and the University of Iowa Hygienic Laboratory (UIHL), studied the occurrence and distribution of nitrate and selected pesticides along the floodplain of the Iowa River in Iowa County. Results of the study indicate variations in nitrate and pesticide concentrations with depth as well as with the season of the year. Nitrate as nitrogen concentrations ranged from less than 0.1 to 19.0 milligrams per liter and typically decreased with distance below the water table. Corn and soybean herbicides also were detected in some samples. These variations indicate that chemical reactions and the movement of ground water affect the distribution and occurrence of nitrate and pesticides. Information from this study will be used by the DNR, the UIHL, and others to make decisions affecting the use and protection of lowa's water resources.

\section{GROUND-WATER MANAGEMENT}

The lowa Department of Natural Resources is the principal State agency responsible for ground-water management. Regulatory functions related to ground-water quality are conducted by the department's Environmental Protection Division. The GSB of the department's Energy and Geological Resources Division performs ground-water investigations and research. This work commonly is done in cooperation between the GSB, the UIHL, and the USGS. The UIHL provides analytical laboratory services to State agencies charged with monitoring and assessing ground-water quality. During fiscal year 1988, the following Federal, State, and local agencies entered into interagency or cooperative cost-sharing agreements with the USGS to conduct ground-water investigations in Iowa:

$$
\begin{aligned}
& \text { Carroll County Health Department } \\
& \text { Guthrie County Health Department } \\
& \text { lowa Department of Natural Resources } \\
& \text { Environmental Protection Division } \\
& \text { Geological Survey Bureau } \\
& \text { U.S. Air Force } \\
& \text { U.S. Army Corps of Engineers } \\
& \text { University of Iowa Hygienic Laboratory }
\end{aligned}
$$

\section{SELECTED REFERENCES}

Buchmiller, Rober, Gaillot, Gary, and Soenksen. P.J., 1985, Water resources of north-central lowa: Iowa Geological Survey Water Atlas Number 7,93 p.

Detroy, M.G., 1985, Iowa ground-water-quality monitoring program: U.S. Geological Survey Open-File Report 84-815, 34 p.

1986, Areal and vertical distribution of nitrate and herbicides in the lowa River alluvial aquifer, lowa County, lowa: Conference on agricultural impacts on ground water, Omaha, Nebr., August 1113, 1986, Proceedings, p. 381-398.

Karsten, R.A., compiler, 1985, Summary of water-resources activities of the U.S. Geological Survey in lowa-fiscal year 1985: U.S. Geological Survey, Iowa City, lowa, 46 p.

U.S. Geological Survey, 1985, National water summary 1984Hydrologic events, selected water-quality trends, and ground-water resources: U.S. Geological Survey Water-Supply Paper 2275, 467 p. 1988, lowa ground-water quality: U.S. Geological Survey OpenFile Report 87-0725, 9 p.

Information on technical reports and data related to ground water in Iowa can be obtained from:

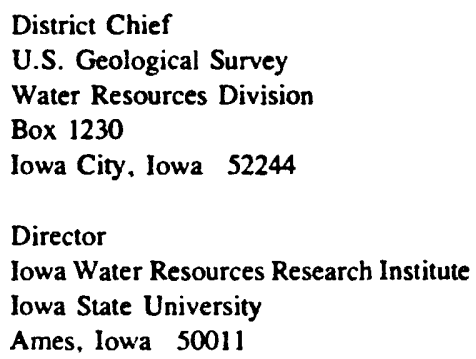

